\title{
Nova HOME PAGE da FEBRASGO
}

A FEBRASGO colocou no ar sua nova "HOME PAGE". Por tratar-se de um número muito grande de informações a serem disponibilizadas, ela está passando por um processo dinâmico de atualização na sua interface gráfica, assim como, na apresentação dos arquivos a serem consultados para possivel "download".

Será mais fácil acessar o "site", ler os arquivos e "baixar" somente o que interessar.

Como toda página na internet, as modificações são executadas quase em tempo real, mas, ainda assim, pode haver algum lapso entre o anúncio de novo serviço e sua disponibilidade.

Durante algum tempo as duas páginas (nova e antiga) estarão juntas, até que possam migrar todas as informações para a nova página.

Esperamos que os tocoginecologistas brasileiros possam utilizar a Home Page da FEBRASGO como forma de buscar informações a cerca de nossa especialidade e atualização.

A Diretoria 